\title{
Volume 24 Index
}

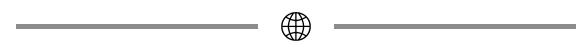

Alois, Paul, "Lessons for Effective Governance: An Examination of the Better Work Program," no. 1 (Jan.-Mar.), pp. 139-158.

Beisheim, Marianne, and Nils Simon, "Multistakeholder Partnerships for the SDGs: Actors' Views on UN Metagovernance," no. 4 (Oct.-Dec.), pp. 497515.

Bishop, Matthew Louis, and Andrew F. Cooper, "The FIFA Scandal and the Distorted Influence of Small States," no. 1 (Jan.-Mar.), pp. 21-40.

Bock, Joseph G., and Ziaul Haque, "Getting a Sharper View of the Humanitarian Marketplace: Introducing Conduit Engagement Theory,” no. 4 (Oct.-Dec.), pp. 517-535.

Carraro, Valentina, and Hortense Jongen, "Leaving the Doors Open or Keeping Them Closed? The Impact of Transparency on the Authority of Peer Reviews in International Organizations," no. 4 (Oct.-Dec.), pp. 615-635.

Chan, Nicholas, "“Large Ocean States": Sovereignty, Small Islands, and Marine Protected Areas in Global Oceans Governance," no. 4 (Oct.-Dec.), pp. 537555.

Chesterman, Simon, "How "Public" Is Public International Law? Toward a Typology of NGOs and Civil Society Actors,” no. 2 (Apr.-June.), pp. 159168.

Egeland, Kjølv, "Banning the Bomb: Inconsequential Posturing or Meaningful Stigmatization?," no. 1 (Jan.-Mar.), pp. 11-20.

Gilson, Julie, "ASEAN and Regional Responses to the Problem(s) of Land Grabbing," no. 1 (Jan.-Mar.), pp. 41-60.

Hartshorn, Ian M., "Global Labor and the Arab Uprisings: Picking Winners in Tunisia and Egypt," no. 1 (Jan.-Mar.), pp. 119-138.

Hein, Wolfgang, and Lars Holstenkamp, "Global Governance and the Interplay of Coordination and Contestation: The Case of Renewable Energies in the South," no. 3 (July-Sept.), pp. 431-449.

Hoekman, Bernard, "Reducing Home Bias in Public Procurement: Trade Agreements and Good Governance," no. 2 (Apr.-June.), pp. 249-265.

Jacob, Cecilia, "From Norm Contestation to Norm Implementation: Recursivity and the Responsibility to Protect," no. 3 (July-Sept.), pp. 391-409.

Jönsson, Christer, and Anders Johnsson, "Parliaments in Global Governance," no. 3 (July-Sept.), pp. 309-320.

Kacowicz, Arie M., "Regional Governance and Global Governance: Links and Explanations," no. 1 (Jan.-Mar.), pp. 61-80.

Kim, Sung-Mi, Sebastian Haug and Susan Harris Rimmer, "Minilateralism Revis- 
ited: MIKTA as Slender Diplomacy in a Multiplex World," no. 4 (Oct.-Dec.), pp. 475-489.

Lilja, Jannie, and Kristine Höglund, "The Role of the External in Local Peacebuilding: Enabling Action-Managing Risk," no. 3 (July-Sept.), pp. 411430.

Nelson-Nuñez, Jami, and Elise Pizzi, "Governance and Water Progress for the Rural Poor,” no. 4 (Oct.-Dec.), pp. 575-593.

Oestreich, Joel E., "The World Bank and the "Equity Agenda": An Assessment After Ten (or So) Years," no. 4 (Oct.-Dec.), pp. 557-574.

Ohanyan, Anna, "The Global Political Economy of Fractured Regions," no. 3 (July-Sept.), pp. 371-390.

Partzsch, Lena, "Take Action Now: The Legitimacy of Celebrity Power in International Relations," no. 2 (Apr.-June.), pp. 229-248.

Pérez Ricart, Carlos A., "The Role of the DEA in the Emergence of the Field of Anti-narcotics Policing in Latin America," no. 2 (Apr--June.), pp. 169-192. Ralph, Natalie, and Linda Hancock, "Exploring the Role of Alternative Energy Corporations in Ethical Supply Chains and Corporate Peacebuilding," no. 1 (Jan.-Mar.), pp. 81-102.

Roper, Steven D., "Applying Universal Jurisdiction to Civil Cases: Variations in State Approaches to Monetizing Human Rights Violations," no. 1 (Jan.-Mar.), pp. 103-118.

Rumsey, Jessie G., "Does Counterterrorism Trump Human Rights? An Analysis of US Foreign Aid Hearings Pre- and Post-9/11," no. 3 (July-Sept.), pp. 351-370.

Rushton, Simon, "Promoting Pro-health Policies Across Regimes: Global AIDS Institutions and the Harm Reduction Debate," no. 2 (Apr.-June.), pp. 267286.

Seyle, Conor, and Roberta Spivak, "Complexity Theory and Global Governance: Is More Different?," no. 4 (Oct.-Dec.), pp. 491-495.

Steinberg, Gerald, and Becca Wertman, "Value Clash: Civil Society, Foreign Funding, and National Sovereignty," no. 1 (Jan.-Mar.), pp. 1-10.

Squatrito, Theresa, "The Democratizing Effects of Transnational Actors' Access to International Courts," no. 4 (Oct.-Dec.), pp. 595-613.

Szczepanska, Kamila, "Toward Inclusive Global Governance? Japanese Civil Society, the State, and G7/8 Summitry, 2000-2016," no. 2 (Apr.-June.), pp. 211-228.

Tansey, Oisín, "Lowest Common Denominator Norm Institutionalization: The Anti-coup Norm at the United Nations," no. 2 (Apr.-June.), pp. 287-306.

Tienhaara, Kyla, and Christian Downie, "Risky Business? The Energy Charter Treaty, Renewable Energy, and Investor-State Disputes," no. 3 (July-Sept.), pp. 451-471.

Tussie, Diana, "Set to Shake Up Global Economic Governance: Can the BRICS Be Dismissed?," no. 3 (July-Sept.), pp. 321-330. 
Vilmer, Jean-Baptiste Jeangène, “The Responsibility Not to Veto: A Genealogy," no. 3 (July-Sept.), pp. 331-349.

Weiss, Thomas G., and Rorden Wilkinson, "The Globally Governed-Everyday Global Governance," no. 2 (Apr.-June.), pp. 193-210. 